\title{
COMMENTARY
}

\section{Inhaled activated protein C: a new therapy for the prevention of ventilator-induced lung injury?}

\author{
Edward Abraham* \\ See related research by Maniatis et al., http://ccforum.com/content/14/2/R70
}

\begin{abstract}
Systemic administration of activated protein C (APC) has been shown to reduce pulmonary inflammation in preclinical models of acute lung injury. However, there is only limited information concerning the effects of inhaled APC in modulating the severity of pulmonary inflammation. In a study reported in this issue of Critical Care, Maniatis and colleagues show that pretreatment of mice with inhaled APC is protective against ventilator-induced lung injury. While the mechanisms responsible for this effect require additional elucidation, inhaled APC appears to be a potentially useful intervention in diminishing the severity of ventilator-induced lung injury and other forms of acute lung injury.
\end{abstract}

Given the multiplicity of anti-inflammatory actions of activated protein $\mathrm{C}$ (APC), it is perhaps not surprising that APC would be effective in reducing the severity of lung injury produced by the use of large tidal volumes during mechanical ventilation. In this issue of Critical Care, Maniatis and colleagues [1] provide data showing that inhaled APC is protective against ventilator-induced lung injury (VILI). The use of inhaled APC in these studies is an intriguing use of this agent and would be expected to target its effects to the airways and alveoli affected by VILI while minimizing systemic effects. Unfortunately, the present study does not provide any information about circulating coagulation parameters or about potential leakage of the inhaled APC into the systemic circulation, so it is unknown at present whether the beneficial effects found in these experiments are due purely to the pulmonary effects of APC or whether

\footnotetext{
*Correspondence: eabraham@uab.edu

Department of Medicine, University of Alabama at Birmingham School of Medicine, 420 Boshell Building, 1808 7th Avenue South, Birmingham, AL 35294, USA
}

inhaled APC can gain access to the circulation, thereby exerting its effects on the lungs and other organs.

In addition to its effects on coagulation cascades, APC has been shown to have a number of actions that may contribute to reducing inflammation in the setting of sepsis or acute lung injury. For example, APC has potent anti-apoptotic effects on endothelial cells that remain even when modified forms of APC that lack anti-coagulant properties are used [2]. Interaction between APC and the endothelial protein $C$ receptor, which is actually a misnomer since this receptor is also found on other cell populations, including neutrophils and mononuclear cells, results in diminished migration toward inflammatory gradients [3]. In human studies in which lipopolysaccharide (LPS) was instilled into airways, there were decreased numbers of neutrophils in the airways among the volunteers randomly assigned to infusions of APC [3]. Recent data have shown that APC cleaves histones released by dying cells, diminishing the damage to endothelial cells and inflammatory responses initiated by exposure to histones [4]. Finally, interaction of APC with protease-activated receptor- 1 can diminish the activation of macrophages and other cell populations [5-7].

While the authors of this article hypothesize that the beneficial actions of inhaled APC in VILI result from inhibition of activation of the extracellular-regulated kinase (ERK) pathway, this potential mechanism is not directly explored. Rather, diminished ERK activation is shown in lung homogenates and in cultured lung epithelial cells after treatment with APC. However, it remains unclear whether the decrease in ERK activation is the cause of the beneficial effects of APC or rather is simply a reflection of the decrease in inflammation produced by APC treatment. Additional experiments in which ERK was specifically inhibited would be necessary to determine the importance of this signaling pathway in modulating the effects of APC in VILI.

Several previous studies have shown that inhaled APC reduces lung injury and inflammation in models of LPSinduced lung injury [8-10]. In those studies, despite decreases in histologic indices of lung injury, neutrophil numbers and concentrations of proinflammatory 
cytokines did not appear to be reduced after APC treatment. In contrast, in at least one study, inhaled APC did reduce the severity of coagulation abnormalities in the lungs [10]. Such results suggest that the beneficial effects of inhaled APC may result from reversing alterations in coagulation and fibrinolysis, which are almost ubiquitous findings in acute lung injury, or possibly from diminishing the enhanced apoptosis of epithelial and other cell populations which accompanies acute lung injury.

In the present experiments, treatment with APC was started before the initiation of injurious ventilation. Therefore, it remains unknown at present whether inhaled APC would be beneficial if initiated after the lungs have been exposed to large tidal volumes, an important clinical issue. Additionally, low-tidal-volume ventilation has become the standard of care in critically ill patients because of studies showing that its use improves outcome, including diminishing mortality, in patients with acute lung injury and also is likely to prevent the development of lung injury when used as the initial mode of ventilation [11-14]. Therefore, the clinically relevant questions now become whether inhaled APC can diminish the severity of lung injury when used in conjunction with low-tidal-volume ventilation in the presence of acute lung injury due to sepsis or other etiologies and whether inhaled APC can prevent or minimize primary or secondary lung damage when low tidal volumes are used for mechanical ventilation.

\section{Abbreviations}

APC, activated protein C; ERK, extracellular-regulated kinase; LPS,

lipopolysaccharide; VILI, ventilator-induced lung injury.

\section{Competing interests}

The author declares that he has no competing interests.

\section{Acknowledgments}

This work was supported, in part, by National Institutes of Health grants GM87748 and HL76206.

Published: 29 April 2010

\section{References}

1. Maniatis NA, Letsiu E, Orfanos S, Kardara M, Dimopoulou I, Nakos G, Lekka ME, Roussos C, Armaganidis A, Kotanidou A: Inhaled activated protein C protects mice from ventilator-induced lung injury. Crit Care 2010, 14:R70.
2. Mosnier LO, Gale AJ, Yegneswaran S, Griffin JH: Activated protein C variants with normal cytoprotective but reduced anticoagulant activity. Blood 2004, 104:1740-1744

3. Nick JA, Coldren CD, Geraci MW, Poch KR, Fouty BW, O'Brien J, Gruber M, Zarini S, Murphy RC, Kuhn K, Richter D, Kast KR, Abraham E: Recombinant human activated protein $C$ reduces human endotoxin-induced pulmonary inflammation via inhibition of neutrophil chemotaxis. Blood 2004, 104:3878-3885.

4. Xu J, Zhang X, Pelayo R, Monestier M, Ammollo CT, Semeraro F, Taylor FB, Esmon NL, Lupu F, Esmon CT: Extracellular histones are major mediators of death in sepsis. Nat Med 2009, 15:1318-1321.

5. Kerschen EJ, Fernandez JA, Cooley BC, Yang XV, Sood R, Mosnier LO, Castellino FJ, Mackman N, Griffin JH, Weiler H: Endotoxemia and sepsis mortality reduction by non-anticoagulant activated protein C. J Exp Med 2007, 204:2439-2448.

6. Bae JS, Yang L, Rezaie AR: Receptors of the protein C activation and activated protein $C$ signaling pathways are colocalized in lipid rafts of endothelial cells. Proc Natl Acad Sci U S A 2007, 104:2867-2872.

7. Mosnier LO, Zlokovic BV, Griffin JH: The cytoprotective protein C pathway. Blood 2007, 109:3161-3172.

8. Waerhaug K, Kuzkov V, Kuklin V, Mortensen R, Nordhus K, Kirov M, Bjertnaes L: Inhaled aerosolised recombinant human activated protein $\mathrm{C}$ ameliorates endotoxin-induced lung injury in anaesthetised sheep. Crit Care 2009, 13:R51.

9. Kotanidou A, Loutrari H, Papadomichelakis E, Glynos C, Magkou C, Armaganidis A, Papapetropoulos A, Roussos C, Orfanos SE: Inhaled activated protein $C$ attenuates lung injury induced by aerosolized endotoxin in mice. Vascul Pharmacol 2006, 45:134-140.

10. Slofstra SH, Groot AP, Maris NA, Reitsma PH, Cate HT, Spek CA: Inhalation of activated protein $\mathrm{C}$ inhibits endotoxin-induced pulmonary inflammation in mice independent of neutrophil recruitment. Br J Pharmaco/ 2006, 149:740-746.

11. Bernard GR: Acute respiratory distress syndrome: a historical perspective. Am J Respir Crit Care Med 2005, 172:798-806.

12. Brower RG, Lanken PN, MacIntyre N, Matthay MA, Morris A, Ancukiewicz M, Schoenfeld D, Thompson BT: Higher versus lower positive end-expiratory pressures in patients with the acute respiratory distress syndrome. N Engl J Med 2004, 351:327-336

13. Ventilation with lower tidal volumes as compared with traditional tidal volumes for acute lung injury and the acute respiratory distress syndrome. The Acute Respiratory Distress Syndrome Network. N Engl J Med 2000, 342:1301-1308.

14. Yilmaz M, Keegan MT, Iscimen R, Afessa B, Buck CF, Hubmayr RD, Gajic O: Toward the prevention of acute lung injury: protocol-guided limitation of large tidal volume ventilation and inappropriate transfusion. Crit Care Med 2007, 35:1660-1666; quiz 1667.

doi:10.1186/cc8977

Cite this article as: Abraham E: Inhaled activated protein C: a new therapy for the prevention of ventilator-induced lung injury? Critical Care 2010, 14:144. 